\title{
Epidermal Growth Factor-like, Corneal Wound Healing Substance in Mouse Tears
}

\author{
Osamu Tsutsumi, Atsuko Tsutsumi, and Takami Oka \\ Laboratory of Molecular and Cellular Biology, National Institute of Diabetes and Digestive and Kidney Diseases, \\ National Institutes of Health, Bethesda, Maryland 20892
}

\begin{abstract}
We have identified the presence of a putative corneal wound healing substance in mouse tears, which has a molecular size and immunological properties similar to those of epidermal growth factor (EGF). The substance was capable of binding to EGF receptors in mouse parenchymal cells and this binding was inhibited by anti-EGF serum. The concentration of the EGF-like substance in the tears of male and female mice was estimated to be $79.3 \pm 7.0$ (SD) $\mathrm{ng} / \mathrm{ml}$ and $76.5 \pm 8.1$ (SD) $\mathrm{ng} / \mathrm{ml}$, respectively, by EGF radioimmunoassay. Removal of the submandibular glands, which produce large amounts of EGF, reduced plasma EGF to an undetectable level and also decreased the concentration of the EGF-like substance in tears to $27.3 \pm 3.9$ (SD) $\mathrm{ng} / \mathrm{ml}$ in male mice and $25.8 \pm 3.7$ (SD) $\mathrm{ng} / \mathrm{ml}$ in female mice. Approximately $50 \%$ of sialoadenectomized (submandibular glands removed) male mice with deep corneal wounds developed severe ocular lesions or loss of sight whereas none of normal male mice with similar wounds did. Topical application of EGF to deeply wounded eyes of sialoadenectomized mice eliminated the various complications and restored the healing rate and incidence of recovery to virtually normal levels.
\end{abstract}

\section{Introduction}

The primary function of tears is to lubricate and protect the corneal epithelium. The cornea serves as a protective layer for the anterior surface of the eye. Corneal epithelial cells possess a high proliferative capacity and thus, when the cornea is injured, regeneration occurs quickly. Since incomplete regeneration of the cornea can lead to ocular scarring, ulceration and visual loss, it is important to identify a growth factor responsible for corneal regeneration for improved treatment of damaged cornea tissue. It is conceivable that tears contain such a wound healing substance.

Epidermal growth factor (EGF) ${ }^{1}$ is produced in large amounts in the submandibular gland of mice (1). This polypeptide $(6,045 \mathrm{~mol} \mathrm{wt})$ is also present in such biological fluids as plasma, milk, urine, and saliva (2-4) but its presence in tears is not known. EGF has been shown to stimulate growth of various mammalian cells in culture, including the corneal cells $(5,6)$, but its function in the body remains largely unclear. In the present study we have identified an EGF-like substance in

Address reprint requests to Dr. Oka, National Institutes of Health, Building 8, Room 304, Bethesda, MD 20892.

Received for publication 13 March 1987 and in revised form 31 August 1987.

1. Abbreviations used in this paper: EGF, epidermal growth factor.

The Journal of Clinical Investigation, Inc.

Volume 81, April 1988, 1067-1071 mouse tears and provided evidence for its physiological role in corneal wound healing.

\section{Methods}

Materials. $\mathrm{C} 3 \mathrm{H} / \mathrm{HeN}$ male and virgin female mice were obtained from the Small Animal Section, National Institutes of Health. They were maintained under conditions of controlled temperature $\left(25^{\circ} \mathrm{C}\right)$ and lighting (light on from 0800 to 2000 hours). Sialoadenectomy (removal of the submandibular glands) was performed on 3-5-mo old animals 3 wk before the experiments. Tears were collected by placing a small piece of preweighed filter paper (Whatman No. 1) in the conjunctival sac for 3 min under ether anesthesia. The volumes of tears collected from normal and sialoadenectomized mice were $1.46 \pm 0.36$, and $1.57 \pm 0.37 \mu 1 /$ eye $/ 3 \mathrm{~min}$, respectively. The tears were eluted from the paper with $250 \mu$ l of phosphate-buffered saline (PBS) containing $1 \%$ (wt/vol) bovine serum albumin (BSA) and $0.1 \%(\mathrm{wt} / \mathrm{vol}$ ) sodium azide. Nearly all of the EGF in each sample $(>90 \%)$ was recovered, as determined by parallel experiments using ${ }^{125}$ I-EGF $(100,000 \mathrm{cpm} ; 170$ $\mu \mathrm{Ci} / \mu \mathrm{g}$; New England Nuclear, Boston, MA) as a carrier. Blood was collected in a heparinized syringe via vena cava and immediately chilled to $4^{\circ} \mathrm{C}$. The plasma was obtained after centrifugation at $8,700 \mathrm{~g}$ for $5 \mathrm{~min}$. The submandibular glands were excised, weighed $(\sim 145$ $\mathrm{mg}$ ) and homogenized in PBS. The homogenates were centrifuged at $12,000 \mathrm{~g}$ for $20 \mathrm{~min}$ and the supernatant was removed and stored at $-20^{\circ} \mathrm{C}$. The average body weights of the normal and sialoadenectomized mice at sacrifice were $28.3 \pm 1.3$ and $28.2 \pm 1.0 \mathrm{~g}$, respectively.

$E G F$ radioimmunoassay. The amounts of EGF and the EGF-like substance were determined by mouse EGF radioimmunoassay as described before (7). Briefly, $100 \mu \mathrm{l}$ diluted tears, plasma, submandibular gland extract, or unlabeled EGF standards ranging from 0.01 to 20 ng/assay (Collaborative Research, Lexington, MA; receptor grade) were mixed with $100 \mu$ l PBS containing ${ }^{125}$ I-labeled EGF $(\sim 15,000$ $\mathrm{cpm}), 1 \%(\mathrm{wt} / \mathrm{vol}) \mathrm{BSA}$ and $0.1 \%$ (wt/vol) sodium azide. Mouse EGF antiserum prepared in rabbits (Collaborative Research), $100 \mu$ l diluted 1:10,000 with the PBS-BSA buffer containing $1 \%$ (vol/vol) normal rabbit serum, was then added. The reaction mixture was incubated for $72 \mathrm{~h}$ at $4^{\circ} \mathrm{C}$. Antibody-bound and free ${ }^{125} \mathrm{I}$-labeled EGF were separated by the use of goat antirabbit immunoglobulin serum (Miles Laboratories, Inc., Elkhart, IN); it was diluted to 1:15 with the PBS-BSA buffer and $200 \mu \mathrm{l}$ added to each tube. The reaction mixture was incubated at $4^{\circ} \mathrm{C}$ for an additional $24 \mathrm{~h}$. The subsequent precipitate was collected by centrifugation at $8,700 \mathrm{~g}$ for $5 \mathrm{~min}$ and washed three times in PBS to remove unbound radioactivity. This assay gave a sensitivity of $0.01 \mathrm{ng}$ EGF per assay, and the intra- and interassay coefficients of variation were 5.5 and $9.7 \%$, respectively.

EGF receptor binding assay. The EGF binding assay was conducted as described (8). Parenchymal cells isolated from male mouse liver $\left(10^{5}\right.$ cells) were incubated with ${ }^{125}$ I-EGF $(40,000 \mathrm{cpm})$ in the absence (control) or presence of the indicated amounts of unlabeled mouse submandibular gland EGF (Collaborative Research; receptor grade, purity $98 \%$ ) or EGF-like substance in tears. After incubation, the cells were washed and the cell-associated radioactivity was counted $(n=3)$. Specific ${ }^{125}$ I-EGF binding was determined by subtracting the amount of radioactivity bound $(260 \mathrm{cpm})$ in the presence of excess unlabeled EGF $(1 \mu \mathrm{g})$. Normal rabbit serum or anti-EGF pretreatment was performed before binding assay by incubating the reaction mixture with normal rabbit serum or EGF antiserum from rabbits at a final 
Table I. Immunoreactive EGF Concentrations in Tears, Plasma, and the Submandibular Gland in Normal and Sialoadenectomized Mice

\begin{tabular}{lccc}
\hline \multicolumn{1}{c}{ Mice } & Tears & Plasma & Submandibular gland \\
& $n g / m l$ & $n g / m l$ & $n g / m g$ wet tissue \\
Male & & & \\
$\quad$ Normal & $79.3 \pm 7.0(n=20)$ & $2.10 \pm 0.70(n=10)$ & $1,450 \pm 140(n=10)$ \\
$\quad$ Sialoadenectomized & $27.3 \pm 3.9^{*}(n=20)$ & $<0.1(n=10)$ & Not applicable \\
Female & $76.5 \pm 8.1(n=15)$ & $0.16 \pm 0.07(n=15)$ & $43 \pm 13(n=15)$ \\
$\quad$ Normal & $25.8 \pm 3.7^{*}(n=15)$ & $<0.1(n=15)$ & Not applicable \\
Sialoadenectomized & & & \\
&
\end{tabular}

The results are given as mean \pm SD. Number of determinations are shown in the parentheses. * Significantly different when compared with normal mice $(P<0.001)$ by Student's $t$ test.

concentration of $0.05 \%$. Subsequent treatment with antirabbit goat serum at a final concentration of $7 \%$ precipitated the antibody-EGF complex in case of anti-EGF pretreatment. This assay gave a sensitivity of $0.01 \mathrm{ng}$ EGF per assay, and provided comparable values of EGF levels to those obtained by radioimmunoassay (8).

Corneal wounding healing. The corneal wounds were induced by placing a piece of paper soaked with either 0.1 or $0.5 \mathrm{M} \mathrm{NaOH}$ on the corneal surface for $10 \mathrm{~s}$ and thereafter washing the eye with 2-3 ml of $0.15 \mathrm{M} \mathrm{NaCl}$ while the animal was under ether anesthesia. EGF treatment was given topically to both normal and sialoadenectomized, 0.5 $\mathrm{M} \mathrm{NaOH}$ treated mice by dropping $4 \mu \mathrm{l}$ EGF solution $(50 \mathrm{ng} / \mathrm{ml} \mathrm{EGF}$ in PBS; Collaborative Research, culture grade, purity $88 \%$ ) into the eye. The other mice were given only PBS drops.

Staining with $2 \%$ fluorescein solution was used to insure complete and uniform wounding and to monitor the wound healing under an ultra violet examination lamp (Burton Medical Products, Van Nuys, CA). After operation, the area of epithelial lesion was measured daily for $15 \mathrm{~d}$ by weighing the $10 \times$ magnified, traced outline of the wound on paper.

Corneal wound healing was also examined histologically at the end of the 15-d experimental period. Eyes were enuculated, fixed in $10 \%$ formalin, embedded in paraffin, cut into $5-\mu \mathrm{m}$ sections and stained with hematoxylin and eosin.

\section{Results}

EGF-like substance in tears. An EGF-like substance, which showed an EGF-antibody binding pattern parallel to that of EGF purified from mouse submandibular gland, was found in mouse tears. The concentration of EGF-like substance in tears of male and female mice was 79.3 77.0 and 76.5 \pm 8.1 (SD) $\mathrm{ng} / \mathrm{ml}$, respectively, as measured by EGF radioimmunoassay. This level is much higher than the level of EGF in plasma (Table I). Gel filtration studies indicated that this substance was eluted at the position of standard mouse submandibular gland EGF having a molecular weight of $\sim 6000$ (data not shown).

In mice, circulating EGF is largely derived from the submandibular gland because sialoadenectomy decreased the circulating EGF to undetectable levels (Table I), as shown previously $(7,9)$. Sialoadenectomy of both male and female mice also reduced the level of the EGF-like substance in tears by as much as $65 \%$ and $67 \%$, respectively, suggesting that this substance may be derived, at least in part, from the circulation.

Biological activity of EGF-like substance in tears. The EGF-like substance in tears bound to EGF receptors in mouse parenchymal cells in a manner similar to that of submandibular gland EGF (Table II). Its binding activity was abolished by treatment with anti-EGF antibody. Preliminary experiments indicated that the EGF-like substance in tears at a diluted concentration of $5 \mathrm{ng} / \mathrm{ml}$ stimulated proliferation of mouse mammary epithelium in culture as EGF does (10), but its biological activity could not be assessed in greater detail because of the limited availability of the substance.

Corneal wound healing. Histological examination indicated that treatment with $0.1 \mathrm{M} \mathrm{NaOH}$ caused superficial erosion without affecting the basal cells and the stroma of the cornea; $0.5 \mathrm{M} \mathrm{NaOH}$ treatment damaged both the entire layer of corneal epithelium and the stroma. The lacrimal systems of mice remained intact after the treatment.

Corneal wound healing took place from the peripheral area to the center. It occurred rapidly in superficial wound while there was one day's delay when deep wound was concerned. In normal male mice, the average time for $50 \%$ healing of the superficial and deep wounds was $0.8 \mathrm{~d}$ and $3.9 \mathrm{~d}$, respectively (Fig. 1 and Table III). The $50 \%$ healing of the corneal wounds

Table II. EGF Receptor Binding Activity of EGF-like Substance in Tears

\begin{tabular}{|c|c|c|}
\hline Condition & $\begin{array}{l}\text { Specific }{ }^{125} \text { I-EGF } \\
\text { binding }\end{array}$ & $\begin{array}{l}\text { Percent displacement } \\
\text { of }{ }^{125} \mathrm{I} \text {-EGF binding }\end{array}$ \\
\hline & $\mathrm{cpm} / 10^{5}$ cells & \\
\hline \multicolumn{3}{|l|}{$\begin{array}{l}\text { Normal rabbit serum } \\
\text { pretreatment }\end{array}$} \\
\hline Control & $4,040 \pm 280$ & \\
\hline EGF $0.1 \mathrm{ng}$ & $3,620 \pm 190$ & 10 \\
\hline EGF $0.5 \mathrm{ng}$ & $2,980 \pm 160$ & 26 \\
\hline EGF $1.0 \mathrm{ng}$ & $2,690 \pm 110$ & 34 \\
\hline EGF $10.0 \mathrm{ng}$ & $663 \pm 50$ & 84 \\
\hline Tears (0.2 ng EGF*) & $3,190 \pm 320$ & 21 \\
\hline Tears (1.0 ng EGF*) & $2,410 \pm 90$ & 40 \\
\hline \multicolumn{3}{|l|}{$\begin{array}{l}\text { Anti-EGF } \\
\text { pretreatment }\end{array}$} \\
\hline Control & $4,540 \pm 350$ & \\
\hline EGF (0.5 ng) & $4,260 \pm 80$ & 6 \\
\hline Tears (0.5 ng EGF*) & $4,550 \pm 480$ & 0 \\
\hline
\end{tabular}

The results are given as mean \pm SD. Percent of displacement of ${ }^{125} \mathrm{I}$ EGF was calculated by comparing the value with that of control. * The concentration of EGF-like substance in tears was estimated by radioimmunoassay. 


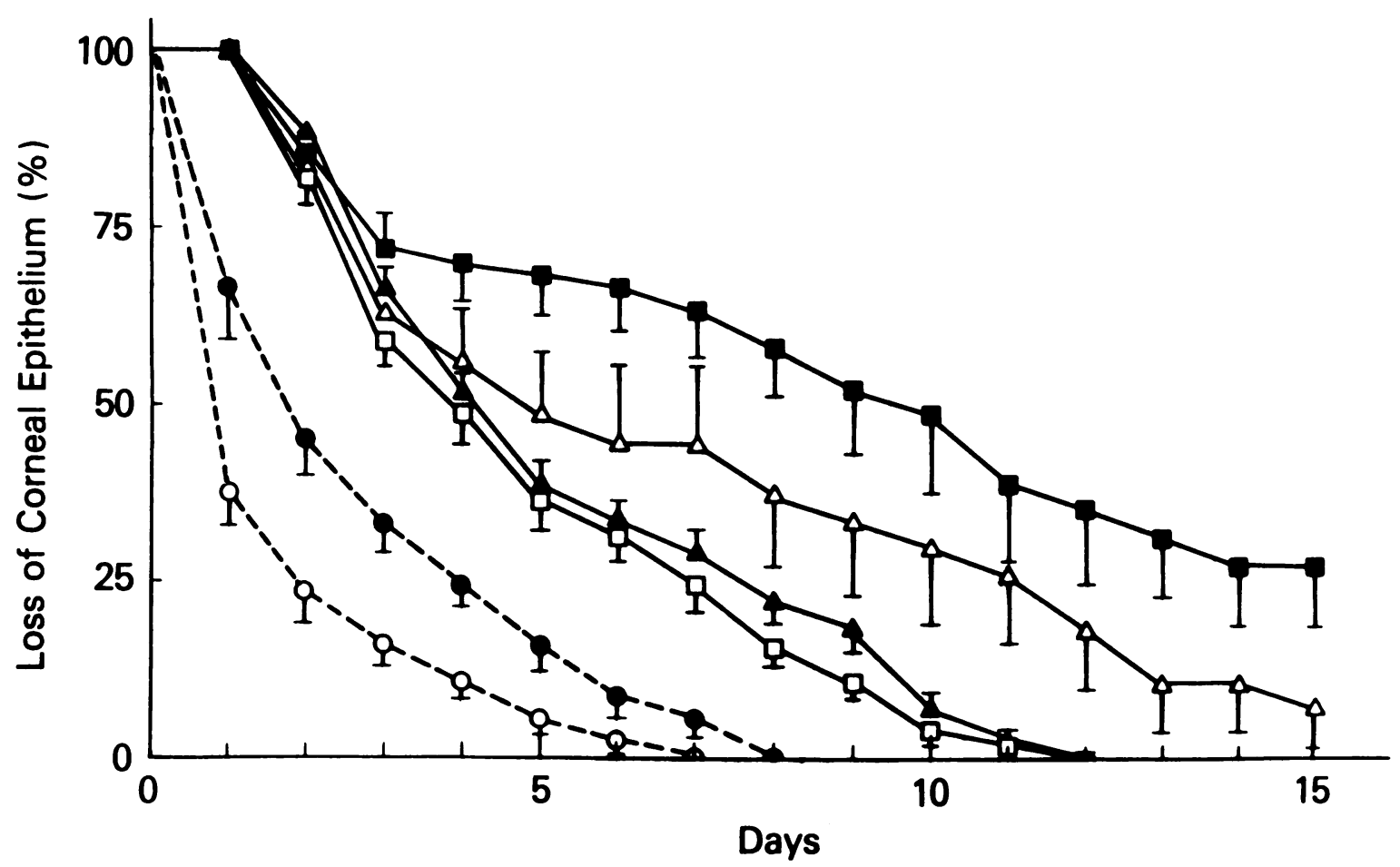

Figure 1. Time-course of epithelial wound healing in male mouse cornea. The corneal wounds were induced by exposing the cornea to either 0.1 or $0.5 \mathrm{M} \mathrm{NaOH}$, which caused superficial or deep wounds in the cornea, respectively. Healing took place from the peripheral area to the center. The percent decrease in the wounded area as a function of time is shown as follows: normal mice exposed to $0.1 \mathrm{M}$ $\mathrm{NaOH}(0)$, sialoadenectomized mice exposed to $0.1 \mathrm{M} \mathrm{NaOH}(\bullet)$,

in sialoadenectomized mice was slower; it took $2.1 \mathrm{~d}$ for superficial wounds and $9.6 \mathrm{~d}$ for deep wounds. The rate of healing of the deep wounds in the sialoadenectomized mice was restored to almost the normal level by topical application of EGF at a dose of $200 \mathrm{ng} /$ eye, four times a day. In normal male mice, however, EGF treatment did not change appreciably the healing rate of the deep wounds.

When corneal wound healing experiments were performed using normal and sialoadenectomized female mice $(n=3-5)$, the results were virtually identical with those obtained with male mice (data not shown). normal mice exposed to $0.5 \mathrm{M} \mathrm{NaOH}(\square)$, sialoadenectomized mice exposed to $0.5 \mathrm{M} \mathrm{NaOH}(\square)$. EGF treatment was given topically to sialoadenectomized, $0.5 \mathrm{M} \mathrm{NaOH}$ treated mice by dropping $4 \mu \mathrm{l}$ EGF solution ( $50 \mathrm{ng} / \mathrm{ml}$ EGF in PBS) into the eye either two $(\Delta)$ or four ( $\Delta$ ) times a day. The other mice were given only PBS. Each group consisted of five to eight mice and both eyes of each mouse received the same treatment. The results were expressed as mean \pm SD.

The superficially wounded corneas in both normal and sialoadenectomized mice healed completely without histological abnormalities anywhere in the tissue as examined at the end of the 15-d experimental period, although healing rate was slower in the latter. In the case of deep wounds affecting the stromal region, the regeneration was very poor in sialoadenectomized mice. $50 \%$ of these animals developed more severe ocular lesions; the regeneration of corneal cells was incomplete and corneal ulcers were present. Some showed descemetocele (herniation of the descemet membrane) or panopthalmitis, whereas others showed considerable degenerative changes

Table III. Corneal Wound Healing in Normal and Sialoadenectomized Mice

\begin{tabular}{llllll}
\hline Wound & \multicolumn{1}{c}{ Mice } & $n$ & Treatment & $\begin{array}{c}\text { Days required } \\
\text { for } 50 \% \text { healing }\end{array}$ & $\begin{array}{c}\text { Percent complete } \\
\text { recovery }\end{array}$ \\
\hline Superficial & Normal & 16 & None & $0.8 \pm 0.1$ & 100 \\
Superficial & Sialoadenectomized & 16 & None & $2.1 \pm 0.4^{*}$ & 100 \\
Deep & Normal & 12 & None & $3.9 \pm 0.4$ & 100 \\
Deep & Normal & 10 & EGF (4 times/d) & $3.8 \pm 0.5$ & 100 \\
Deep & Sialoadenectomized & 12 & None & $9.6 \pm 1.0^{*}$ & $50^{\ddagger}$ \\
Deep & Sialoadenectomized & 10 & EGF (2 times/d) & $4.7 \pm 0.7^{*}$ & 80 \\
Deep & Sialoadenectomized & 10 & EGF (4 times/d) & $4.1 \pm 0.5$ & 100 \\
\hline
\end{tabular}

The experimental wounds were produced as described in the text. A wound was judged to be completely healed when regenerated epithelium covered the whole cornea during $15 \mathrm{~d}$ of experimental period. $n$, the number of the eyes examined. * Significantly different when compared with normal mice with the corresponding corneal wound $(P<0.01)$ by Student's $t$ test. ${ }^{\ddagger}$ Significantly different from normal mice having deep corneal wound $(P<0.01)$ by $\chi^{2}$ test. 
(Fig. $2 c$ ). EGF treatment of sialoadenectomized mice greatly improved the incidence of healing of the wounded corneas and eliminated the various complications (Fig. $2 d$ ).

\section{Discussion}

Our present results indicate that tears contain an EGF-like substance that has some immunological, physicochemical, and biological properties similar to those of the submandibular gland EGF. However, identification of this substance as EGF requires purification and determination of its chemical composition.

The concentration of the EGF-like substance in tears was approximately 40-fold higher than that of plasma EGF in normal male mice (Table I). Sialoadenectomy decreased the circulating EGF to undetectable levels and also reduced the EGF-like substance level in tears by as much as $65 \%$. Similar results were obtained with female mice. Moreover, our preliminary experiments showed that subcutaneous injection with
EGF ( $5 \mu \mathrm{g} /$ mouse) increased the concentration of EGF-like substance in tears by twofold within $30 \mathrm{~min}$ and that ${ }^{125} \mathrm{I}$-labeled EGF injected i.p. into mice appeared in tears within 15 min. It is also reported that labeled EGF injected intraperitoneally into rat was concentrated in the epithelial cells of the cornea, suggesting that EGF can move from the circulation into tears (11). These findings suggest that the tear gland sequesters and concentrates circulating EGF derived from the submandibular gland and secretes it into tears. Recently, Gresik showed that the other secretory tissue, lactating mouse mammary gland, possesses the similar ability to sequester and transport EGF into the milk (12). However, our data also showed that the concentration of the EGF-like substance in the tears was virtually the same in male and female, although male mice have much higher levels of EGF in the submandibular gland and plasma than females. In addition, sialoadenectomy, which decreased the circulating EGF to undetectable levels, reduced the level of the EGF-like substance in tears by $65 \%$ and $67 \%$, respectively, in male and female animals. These
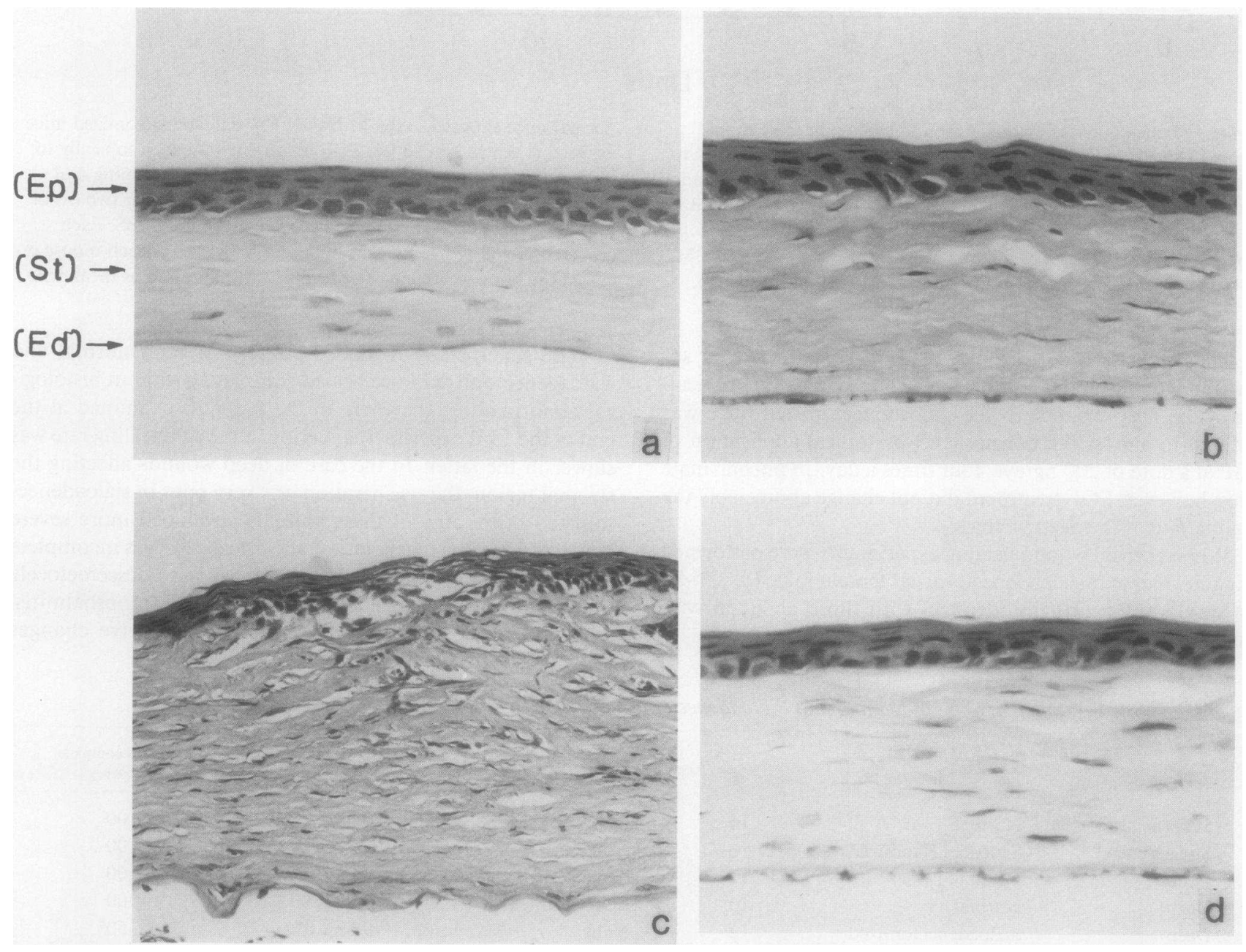

Figure 2. Histology of the cornea. Sections of the eye were obtained at the end of 15-d experimental period. Three major constituents of the cornea, epithelial (Ep), stromal (St) and endothelial (Ed) layers, are shown. $(a)$ normal cornea $(\times 430)$. $(b)$ completely healed cornea from normal mouse $(\times 430)$. $(c)$ cornea of sialoadenectomized mouse $(\times 220)$. Epithelial disarticulation is present and the stromal layer is enlarged and infiltrated by macrophages. The endothelial layer also shows degenerative changes. $(d)$ cornea of EGF treated-sialoadenectomized mouse $(\times 430)$. All the layers show apparently normal appearance, like that of the normal mouse with similar wounding. Cornea wounds were induced by treatment with $0.5 \mathrm{M} \mathrm{NaOH}$ as described in the Fig. 1 legend. These histological sections are representative of each experimental group. 
results raise the possibility that the tear gland itself may synthesize and secrete some portion of the EGF-like substance and this function may be regulated, at least partly, by the circulating EGF. It would be of interest to examine the production of EGF in the tear gland by use of the complementary DNA probe for EGF that has been made available recently (13).

The data presented in this study suggest that the EGF-like substance in tears may have an important physiological function in corneal wound healing. In sialoadenectomized mice, which have lower concentrations of the EGF-like substance in tears, corneal wound healing was substantially slowed and the prognosis for a severely damaged cornea was very poor. However, topically applied EGF greatly enhanced corneal healing. In normal mice, whose tears contained higher concentrations of EGF-like substance, the effect of exogeneously applied EGF was not apparent. In addition, it has been shown that the cornea possesses EGF receptors $(14,15)$ and EGF stimulates proliferation of epithelial and endothelial cells of the cornea in culture $(5,6)$. These results are also consistent with the view that EGF plays a role in the corneal regeneration. EGF has been shown to promote epithelial healing in the rabbit cornea $(14,16-18)$. However, these studies differ from the present work in that sialoadenectomy was not employed to assess the effect of EGF deficiency in tears and circulation on corneal wound healing. In addition, possible presence of EGF-like substance in rabbit tears was not examined. Moreover, relatively high concentrations of EGF $(0.05-2.0 \mathrm{mg} / \mathrm{ml})$ were required for healing of superficial corneal wounds in rabbits (14, $16,17)$. It is possible, however, that importance of the submandibular glands in corneal wound healing is restricted to the mouse, since it is the only known animal that has such a huge concentration of EGF in the submandibular glands and in which there is free EGF in plasma that is derived from the submandibular glands.

The results of clinical attempts to demonstrate the beneficial effect of EGF on corneal wound healing have been equivocal (19-21). This may be due to the fact that EGF is also present in human tears at varying concentrations (our unpublished data). Based on the present study, EGF therapy for corneal wounds may be warranted in some disease conditions if EGF were deficient in tears. This therapy might be applicable in the case of persistent corneal ulcers or disorders of lacrimation.

\section{Acknowledgments}

We thank Drs. E. J. Baas, B. J. Carter, C. Edwards, I. G. Leder, H. Pollard, J. Robbins, F. Tietze, Y. Uchida, and S. H. Wollman for helpful discussion and critical reading of the manuscript.

\section{References}

1. Cohen, S. 1962. Isolation of a mouse submaxillary gland protein accelelating incisor eruption and eyelid opening in the new-born animal. J. Biol. Chem. 237:1555-1562.
2. Byyny, R. L., D. N. Orth, S. Cohen, and E. S. Doyne. 1974. Epidermal growth factor: effects of androgens and adrenergic agents. Endocrinology. 95:776-782.

3. Hirata, Y., and D. N. Orth. 1979. Concentrations of epidermal growth factor, nerve growth factor, and submandibular gland renin in male and female mouse tissue and fluids. Endocrinology. 105:13821387.

4. Barka, T. 1980. Biologically active polypeptide in submandibular glands. J. Histochem. Cytochem. 28:836-859.

5. Carpenter, G. 1978. The regulation of cell proliferation: advances in the biology and mechanism of action of epidermal growth factor. J. Invest. Dermatol. 72:283-287.

6. Hyldahl, L. 1985. Proliferation of human embryonic corneal stromal cells in a serum-free medium. Cell Biol. Int. Rep. 9:655-662.

7. Kurachi, H., and T. Oka. 1985. Changes in epidermal growth factor concentrations of submandibular gland, plasma and urine of normal and sialoadenectomized female mice during various reproductive stages. J. Endocrinol. 106:197-202.

8. Okamoto, S., and T. Oka. 1985. Effect of pregestational sialoadenectomy of nursing mothers on eyelid opening of pups. Am. J. Physiol. 18:R285-289.

9. Tsutsumi, O., H. Kurachi, and T. Oka. 1986. A possible physiological role of epidermal growth factor in male reproductive function. Science (Wash. DC). 233:975-977.

10. Taketani, Y., and T. Oka. 1983. Biological action of epidermal growth factor and its functional receptors in normal mammary epithelial cells. Proc. Natl. Acad. Sci. USA. 80:2647-2650.

11. Covelli, I., R. Rossi, R. Mozzi, and L. Frati. 1972. Synthesis of bioactive ${ }^{131} \mathrm{I}$-labeled epidermal growth factor and its distribution in rat tissue. Eur. J. Biochem. 27:225-230.

12. Gresik, E. W., H. Van Der Noen, and T. Barka. 1984. Transport of ${ }^{125} \mathrm{I}$-EGF into milk and effect of sialoadenectomy on milk EGF in mice. Am. J. Physiol. 247:E349-354.

13. Gray, A., T. J. Dull, A. Ullrich, and W. Ford. 1983. Nucleotide sequence of epidermal growth factor cDNA predicts a 128,000-molecular weight protein precursor. Nature (Lond.). 303:722-725.

14. Frati, L., S. Daniele, A. Delougu, and I. Covelli. 1972. Selective binding of the epidermal growth factor and its specific effects on the epithelial cells of the cornea. Exp. Eye Res. 14:135-141.

15. Fabricant, R. N., A. J. Alpar, Y. M. Centifanto, and H. E. Kaufman. 1981. Epidermal growth factor receptors on cornal endothelium. Arch. Ophthalmol. 99:305-308.

16. Savage, C. R., Jr., and S. Cohen. 1973. Proliferation of corneal epithelium induced by epidermal growth factor. Exp. Eye Res. 15:361-366.

17. Ho, P. C., W. H. Davis, J. H. Elliott, and S. Cohen. 1974. Kinetics of corneal epithelial regeneration and epidermal growth factor. Invest. Ophthalmol. 13:804-809.

18. Woost, P. G., J. Brightwell, R. A. Eiferman, and G. P. Schultz. 1985. Effect of growth factors with dexamethasone on healing of rabbit corneal stromal incisions. Exp. Eye Res. 40:47-60.

19. Elliott, J. H. 1980. Epidermal growth factor: in vivo ocular studies. Trans. Am. Ophthalmol. Soc. 78:629-656.

20. Kandarakis, A. S., C. Page, and H. E. Kaufman. 1984. The effect of epidermal growth factor on epithelial healing after penetrating keratoplasty in human eyes. Am. J. Ophthalmol. 98:411-415.

21. Daniele, S., L. Frati, C. Fiore, and G. Santoni. 1979. The effect of epidemal growth factor on the corneal epithelium in humans. Albrecht v. Graefes Arch. Klin. Exp. Ophthal. 210:159-165. 